Article

\title{
Assessing Sustainability Performance at the Farm Level: Examples from Greek Agricultural Systems
}

\author{
Irene Tzouramani ${ }^{1, *(\mathbb{C}}$, Stamatis Mantziaris ${ }^{1,2}\left(\mathbb{D}\right.$ and Pavlos Karanikolas ${ }^{2}(\mathbb{C}$ \\ 1 Agricultural Economics Research Institute, Hellenic Agricultural Organization, Athens 11528, Greece; \\ sta.athens@hotmail.com \\ 2 Department of Agricultural Economics and Rural Development, Agricultural University of Athens, \\ Athens 11855, Greece; pkaranik@aua.gr \\ * Correspondence: tzouramani@agreri.gr
}

Received: 29 February 2020; Accepted: 3 April 2020; Published: 7 April 2020

\begin{abstract}
In recent years, farmers and policymakers have faced ample challenges and have struggled to support the sustainability of the agricultural sector. Sustainable agriculture encompasses multiple concepts, and its performance produces extensive debate about data requirements, appropriate indicators, evaluation methods, and tools. Under the European Union (EU) financed project FLINT (Farm Level Indicators for New Topics in policy evaluation), detailed data have been collected at the farm level to provide broader coverage of sustainability indicators on a wide range of relevant topics to facilitate the assessment of sustainability performance. The approach has been applied in a pilot network of representative farms at the EU level, considering the heterogeneity of the EU farming sector to provide data infrastructure with up to date information for sustainability indicators. This study aims to assess sustainability performance at the farm level in Greece. Representative and dominant agricultural systems, such as permanent crops, olive trees, arable crops, and livestock (sheep) farms, comprise the Greek sample. It uses the analytical hierarchy process (AHP) methodology and attempts to gain insights into the sustainability performance of agricultural systems. The outcome of the sustainability assessment reveals knowledge and develops support for strategic farm choices in order to support both farmers and policymakers towards more sustainable development plans. The results indicate that three typical Mediterranean farming systems, namely permanent crops, olive trees, and extensive livestock systems (sheep farms), are more sustainable in contrast to intensive and arable crop farms.
\end{abstract}

Keywords: sustainability assessment; farm level; AHP methodology; agricultural policy; Greece

\section{Introduction}

Today, there is growing interest in assessing the sustainability of agriculture. Sustainability has become a high priority, both in scientific research and in policy agendas [1]. Despite the existence of many studies examining particular dimensions, the need for an integrated assessment of sustainability at the farm level has been widely recognized in scholarly research [2-9]. This realization is a result of the sustainability concerns of citizens, as well as frequent policy changes, which create new information needs for all sustainability dimensions at the farm scale $[10,11]$. In the concurrent consideration of the multifaceted nature of sustainability at the farm level, diverse methods for the measurement of indicators and the aggregation of scores have been used [12,13]. The most frequently used methods include tools, frameworks, and indices based on indicators. These are followed by multi-criteria methods, including the analytical hierarchy process (AHP) [9,14-18].

However, the above task is hampered by the complexity of the sustainability concept and the heterogeneity of agricultural systems [19], as well as the limited availability of data, which could 
possibly allow the calculation of meaningful and relevant indicators [20]. Besides the lack of data at the farm level, recent research has pointed out the need to broaden the scope and complement well-established monitoring tools, such as farm accountancy data networks (FADN) [10,20]. Also, any effort for the assessment of sustainability involves various controversial issues, including the process of computing composite indicators, which encompass much information from multiple indices $[6,9,11]$.

The sustainability assessment of Greek agriculture is crucial and could provide vital information for an appropriate strategy that will support its improvement. Greek agriculture features a high degree of sectorial and spatial heterogeneity, as well as a prevailing small-scale structure. In addition, various farming systems of crucial importance are extensive. For example, the average density in olive orchards is 139 trees per hectare (ha), which is much lower than the threshold of intensive systems (more than 180 trees per ha) [21,22]. Similarly, the extensive production system is dominant in sheep rearing, with $78 \%$ of the Greek sheep flocks being reared in low-input production systems [23]. On the other hand, Greek agriculture presents some noteworthy distinctive features compared to the majority of EU countries, such as the highest share of permanent crops (tree cultivations and vineyards) in the total utilized agricultural area (UAA) among EU countries [24], as well as large numbers for sheep and goat rearing, mainly for the production of dairy products rather than meat.

As a part of the broader Mediterranean region, Greek agriculture is facing a series of challenges with clear sustainability implications, such as fragile social structures, the intensive exploitation of natural resources, increasing risks of droughts and biodiversity loss, decrease in crop yields, and rising demand for water $[25,26]$. At the same time, the long-term viability of farms is in jeopardy, all the more so because most of them are small and are less powerful actors in a rapidly consolidating agri-food system. All these challenges undoubtedly imply a necessity for a multidimensional sustainability assessment at the level of farms. It has to be noted that, with a few exceptions [27-29], the literature on this critical issue is scant in regard to Greek agriculture.

This study aims to conduct a comparative assessment of the sustainability performance of various agricultural sectors by using an AHP method to aggregate sets of economic, social, and environmental sustainability indicators. To this end, we use data from different sources, including farm-level data from FADN, complemented with additional data from the EU FLINT project (Farm Level Indicators for New Topics in policy evaluation), along with expert opinions and stakeholder views. This synthetic approach is applied across the professional farms of four typical farming systems in Greece, i.e., arable crops, olive trees, permanent crops, and livestock. All these sectors account for nearly half of the total output of Greek agriculture [30], while they are vital for many rural areas of the country. In addition, these systems are characteristic not only for Greece but also for many other Mediterranean countries.

The paper is organized as follows. Firstly, the applied methodology and the data used in the study are described. Secondly, the empirical application is then presented, followed by the discussion of the results. Finally, the paper concludes by reporting the main findings.

\section{Materials and Methods}

\subsection{Analytical Hierarchy Process}

The analytical hierarchy process (AHP) method was employed here to assess the sustainability of performance at the farm level. The AHP method can be useful in addressing sustainability issues since it can accommodate conflicting, multi-dimensional, and incommensurable sets of objectives [31] and is considered by many as the most reliable multiple criteria decision analysis (MCDA) method [18]. The AHP methodology has been used widely, either alone or in combination with other MCDA methods such as Preference Ranking Organization Method for Enrichment of Evaluations (PROMETHEE), Elimination Et Choix Traduisant la Realité (ELECTRE), Technique for Order of Preference by Similarity to Ideal Solution (TOPSIS) for the sustainability assessment of various aspects of the agricultural sector (e.g., agricultural production models, cultivation techniques, farm types, public policies, and conceptual issues such as development models, etc.) and various regions. 
More specifically, the AHP has been implemented in the comparative sustainability analysis of agricultural production models (organic, integrated, and conventional) for the cultivation of the olive trees in the Mediterranean [32,33]. The sustainability levels of alternative cultivation techniques have also been estimated, such as the tillage practices of maize in Poland [34] and irrigation management alternatives in Portugal [31]. Important agricultural regions in China and Romania have been assessed from the sustainable agricultural point of view $[35,36]$. Furthermore, the dimension of farm-type sustainability has been investigated in the cases of the irrigated agriculture of the Duero Basin in Spain [37] and dairy farming and its possible geographic variability in Portugal [38]. Also, the prioritization of public policies has been analyzed through AHP to support farmer livelihoods in sugarcane growing regions in Brazil under the three pillars of sustainability [39]. Appropriate conceptual models, such as sustainable agricultural development and ethics models in Iran, have been determined via the AHP methodology [40,41].

In the case of Greece, the AHP has been implemented to evaluate the most sustainable farm management practice for the cultivation of Pistacia vera L. on the island of Aegina [28], but also to identify the optimum locations for adoption, and the formation of precision farming clusters as a sustainable solution in the region of Central Macedonia, Greece [18]. Alternative multi-criteria methods have also been applied for sustainability analysis of the agricultural sector in Greece. Dantsis et al. [27] applied multiple attribute value theory to evaluate the sustainability of farms in two geographical regions [42], and Papathanasiou et al. [43] applied TOPSIS and VIseKriterijumska Optimizacija I Kompromisno Resenje (VIKOR) methods to classify the rural areas of Central Macedonia in northern Greece using a set of social sustainability indicators. Although MCDA methods have been used for sustainability analysis in Greek rural areas, the current study presents a comprehensive sustainability analysis, taking into account the three major types of farming (arable farming, tree farming, and livestock farming).

\subsection{Description of the Main Methodological Issues and AHP}

The AHP method was developed by Saaty [44] and is considered an efficient method for dealing with multiple criteria for decision-making problems, aiming to find the optimal choice among alternatives, based on the objective set, taking into account a set of criteria. The steps for applying the AHP method are described below.

\subsubsection{Development of the AHP Model}

The first step corresponds to the structure of the decision within a hierarchical model. The decision problem is structured at different levels of the hierarchy, which are usually three or four; in particular, level 1 of the hierarchy corresponds to the objective, level 2 to the criteria, level 3 to the sub-criteria, and level 4 to the alternatives. As can be seen, in our research, we included four levels of the hierarchy (see Section 2.4.3).

\subsubsection{Determining Local Priorities (Weights) for the Sub-Criteria and Criteria}

A pairwise comparison matrix is filled, referred to as A (Saaty's hierarchy matrix). It contains the performance of each criterion (or sub-criterion) against each other, taking into consideration expert judgment [45].

Saaty [44] suggested a scale from 1 to 9 in order to determine the preference intensity among criteria or sub-criteria (see Table 1). The subsequent rules must be followed when constructing the comparison matrix:

- If $\mathrm{a} i j=\mathrm{a}$, then $\mathrm{a} j i=1 / \mathrm{a}$;

- If criterion or sub-criterion $i$ has equal importance to criterion or sub-criterion $j$, respectively, then $\mathrm{a} i j=\mathrm{aji}=1$, so $\mathrm{a} i \mathrm{i}=1$ for all $i[45]$. 
Table 1. Evaluation scale for pairwise comparisons.

\begin{tabular}{cc}
\hline Verbal Evaluation & Value \\
\hline The two factors are of equal importance & 1 \\
$i$ element is slightly more important than $j$ & 3 \\
$i$ element is clearly important than $j$ & 5 \\
$i$ is much more important than $j$ & 7 \\
$i$ is extremely more important comparing with $j$ & 9 \\
Intermediate values & $2,4,6,8$ \\
\hline
\end{tabular}

Source: [45].

After constructing the pairwise comparison matrix A, its consistency should be checked by following the four steps below:

1. Calculation of $\mathrm{A}^{*} W^{T}$, where $W$ concerns the criteria or sub-criteria weights. In more detail, the evaluation of the weights $W_{1} \ldots W n$ of the criteria or sub-criteria is made as follows:

(1) Each element of column $i$ of the comparison matrix A is divided with the sum of the column. This results in a normalized table whose sum equals 1

(2) Calculation of mean value of row $i$ in the normalized table [45].

2. Calculation of the largest eigenvector $(\lambda \max )$ :

$$
\frac{1}{n} \sum_{i=1}^{n} \frac{i^{\text {th }} \text { entry in } A W}{i^{\text {th }} \text { entry in } W}
$$

where $n$ corresponds to the dimension of the pairwise comparison matrix [45].

3. Estimation of the consistency index $(C I)$ :

$$
C I=\frac{(\lambda \max )-n}{n-1}
$$

The lower levels of the consistency index $(C I)$ are associated with lower levels of inconsistency, which is desirable.

4. The consistency index $(C I)$ estimated in the previous step is compared with the random index $(R I)$, which is the mean $C I$ of 500 randomly filled matrices [46]. The indicator derived from this comparison is the consistency ratio $(C R)$ :

$$
C R=\frac{C I}{R I}
$$

The acceptable level of the $C R$ may not exceed $10 \%$; however, some authors have suggested that the acceptable level of the $C R$ may expand to $20 \%[34,47]$

In order to prioritize the economic sub-criteria, AHP pairwise comparison questionnaires were distributed to experts at the Agricultural University of Athens, the Agricultural Economics Research Institute, and the Technical University of Crete. Among the completed questionnaires, those who achieved a $C R \leq 10 \%$ or those who marginally exceeded this threshold were taken into account in our analysis. We then calculated the average of their weights for each sub-criterion to derive the final local priorities of the economic sub-criteria. In the case of the hierarchy process of social and environmental sub-criteria, the averages of experts' responses to the European Union project FLINT were used. Within the FLINT project, the hierarchy process was implemented via a scale from 2 to -2 (where $2=++; 1=+; 0=+/-;-1=-;-2=--$ ) and then incorporated by the authors into the pairwise comparison matrix. After completing the comparison matrices, the consistency test was carried out, where the $C R$ received values of less than $4 \%$ in both categories of the sub-criteria. At this point, 
it should be noted that the weights of the criteria (level 2) were not determined by experts but preferred to apply a variety of distributions (scenarios), with emphasis on a different criterion each time. The baseline scenario corresponds to the distribution of $0.33 / 0.33 / 0.33$ among the three criteria considered, namely, the environmental, social, and economic criteria. In the case of the preferred scenario, the distribution was broken down to $0.5 / 0.25 / 0.25$. For example, in the case of the environmental preference scenario, the weight for environmental criterion equaled 0.5 , while, for each of the other two criteria, they equaled 0.25 .

\subsubsection{Determining Local Priorities for the Alternatives}

For each sub-criterion, the performances of the alternatives were compared via pairwise comparisons using a scale of 1 to 9 as before (Section 2.2.2). Additionally, consistency tests were performed in the process of evaluating the performance of the alternatives for each sub-criterion, where the $C R$ was limited to values below $5 \%$. Then, the weight of each sub-criterion was multiplied by the corresponding performance of each alternative and then summed up to estimate the local priorities of alternatives for each criterion (or performance for each criterion, namely environmental, social and economic performance). The performances of alternatives for each criterion or sub-criterion sum to 1 .

\subsubsection{Determining Overall Priorities for the Alternatives and Sensitivity Analysis}

In order to determine the overall priorities (or performances) of the alternatives, we synthesized the performance of each alternative for each criterion and the weight of the corresponding criterion, which was determined in the form of the scenarios mentioned above. More specifically, the performances of alternatives for each criterion were multiplied by the corresponding criteria weights and summed up to calculate the overall performances of the alternatives.

\subsection{Data Collection and Sample Description}

Data were collected in the framework of the European research project FLINT, whose primary objective was to provide indicators for assessing agriculture sustainability at the farm level to support policy evaluation [10]. A wide range of indicators have been organized to cover several sustainability themes and merged with the FADN database, where economic indicators are dominant [6]. The Greek case study collected data from the most prevailing farming types in the country, including permanent crops, olive tree farms, arable crops farms, and livestock (sheep) farms. The optimal farm selection plan was based on two determinant factors, namely, the farm holding had to be part of the FADN, following the design of the selection plan on FADN structure covering the farming type and farm economic size classes, and willingness of the farmer to cooperate. In Greece, a sample of 124 agricultural holdings was selected, following the goal to have at least 25 observations per principal type of farming. The data were collected with educated data collectors via face-to-face interviews in the spring of 2016, referring to the calendar year of 2015.

The Greek survey took place in different geographical areas according to the locations of the farming types. Arable crops farms are located in the regional unit of Serres, cultivating mainly irrigated crops such as maize, cotton, and alfalfa (Figures 1 and 2). These farms have the highest percentage of irrigated land (76.5\%) compared to other types of the surveyed farms, and the vast majority of them are in lowland areas (87\%) (Table 2). The olive tree farms are located in the regional units of Laconia and Messinia (Figure 2). Almost all of the cultivated land is occupied by olives, mainly non-irrigated (Figure 1). The irrigation rate corresponds to $42.5 \%$, and the majority of farms are in lowland areas $(46 \%)$ (Table 2). The permanent crop farms of the survey are mainly located in the regional units of Laconia and Messinia (Figure 2). The distribution of crops consists mostly of trees such as olives and oranges (Figure 1). The percentage of irrigated land is $42.2 \%$, and the majority of farms are in lowland areas (53\%) (Table 2). Finally, regarding the livestock farms of the survey, they are located in the regional units of Ioannina and Laconia (Figure 2). The average number of sheep corresponds to 25.9 livestock units, and the mainland uses correspond to pastures and the cultivation of animal feeds such as alfalfa (Figure 1). The percentage of irrigated land is $8.9 \%$ of total land, which is by far the 
smallest compared to the other studied farm types, and the majority of farms are in mountainous areas (50\%) (Table 2).

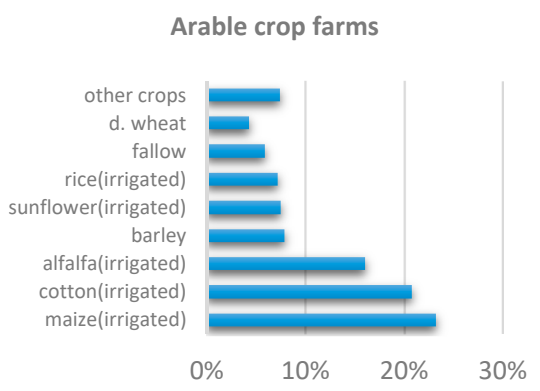

(a)

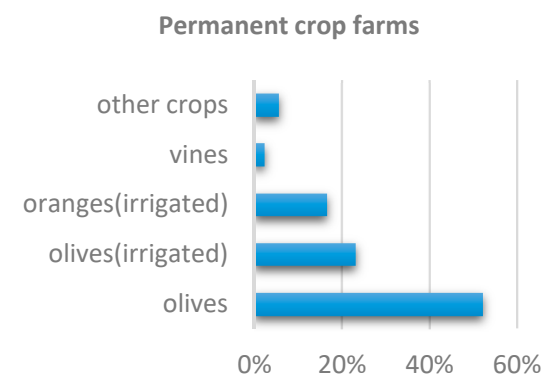

(c)

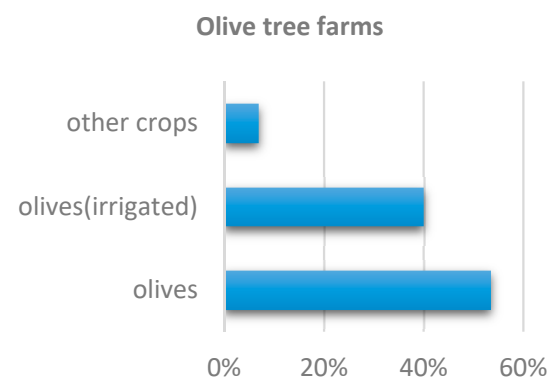

(b)

Livestock farms

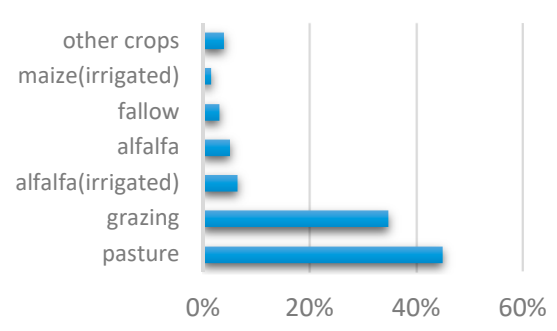

(d)

Figure 1. Crop allocation per farming system; (a) arable crop farms; (b) olive tree farms; (c) permanent crop farms; (d) livestock farms.

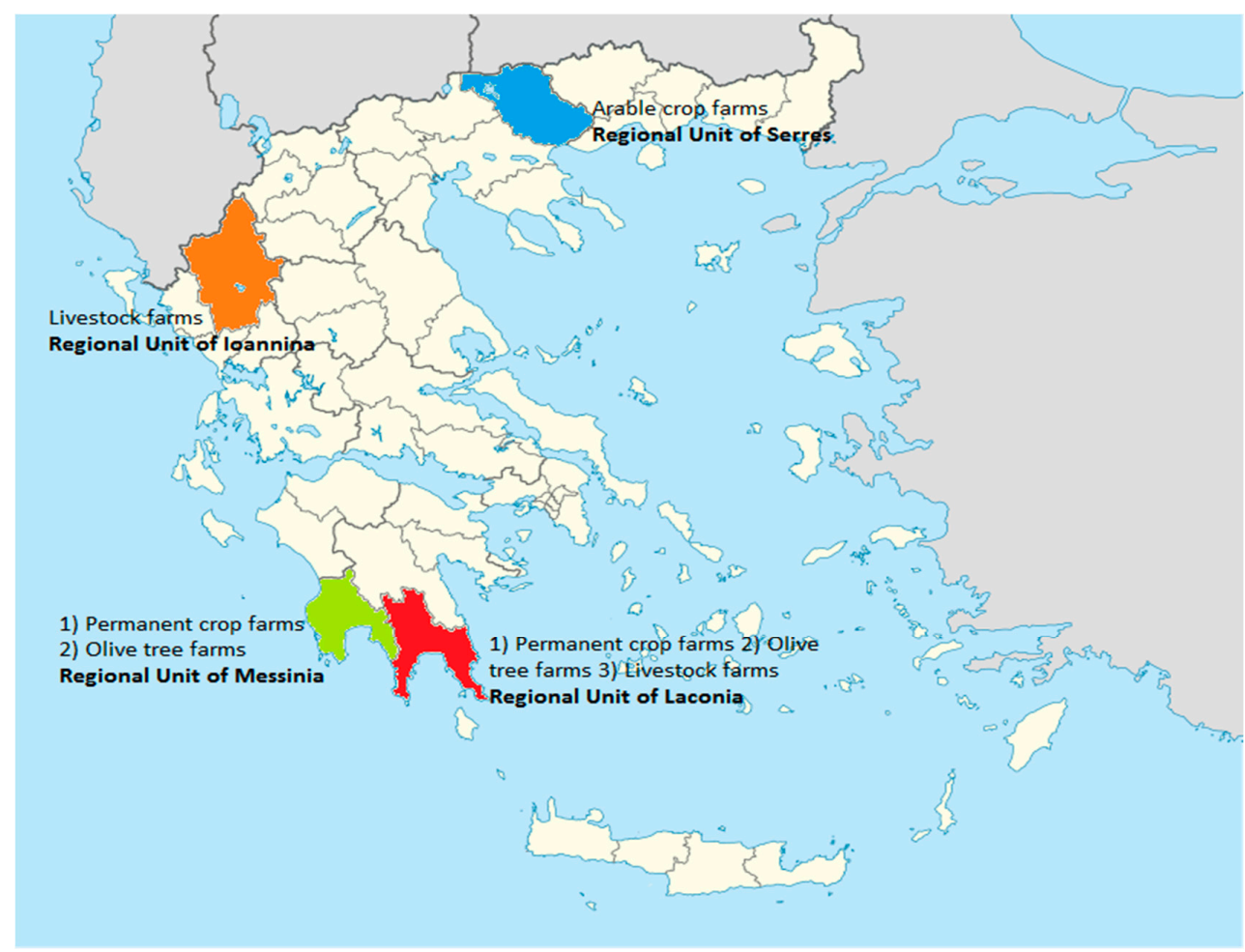

Figure 2. Locations of the sample farms. 
Table 2. Descriptive statistics of the Greek sample.

\begin{tabular}{|c|c|c|c|c|}
\hline Variables & $\begin{array}{c}\text { Permanent Crop } \\
\text { Farms }\end{array}$ & Olive Tree Farms & $\begin{array}{l}\text { Arable Crop } \\
\text { Farms }\end{array}$ & Livestock Farms \\
\hline Holder's average age (years) & 52.6 & 50.8 & 50.2 & 53.6 \\
\hline Total size or total utilized agricultural area (UAA) ha & 248.8 & 225.3 & 330.8 & 537.9 \\
\hline Average size (UAA) ha & 7.8 & 9.8 & 22 & 22.4 \\
\hline Irrigated land (\% of UAA) & $42.1 \%$ & $42.5 \%$ & $76.5 \%$ & $8.9 \%$ \\
\hline Average livestock units of sheep & - & - & - & 25.9 \\
\hline Altitude $<300 \mathrm{~m}$ as a percentage of farms & $53 \%$ & $46 \%$ & $86.7 \%$ & $8 \%$ \\
\hline Altitude $300-600 \mathrm{~m}$ as a percentage of farms & $19 \%$ & $29 \%$ & $6.7 \%$ & $42 \%$ \\
\hline Altitude $>600 \mathrm{~m}$ as a percentage of farms & $28 \%$ & $25 \%$ & $6.7 \%$ & $50 \%$ \\
\hline Gender of farm manager ( $\%$ female) & $37 \%$ & $42 \%$ & $16 \%$ & $16 \%$ \\
\hline \multicolumn{5}{|c|}{ Degree of agricultural education of farm manager } \\
\hline Only practical agricultural experience & $24 \%$ & $32 \%$ & $44 \%$ & $53 \%$ \\
\hline Basic agricultural training & - & - & $4 \%$ & $17 \%$ \\
\hline Full agricultural training & $76 \%$ & $68 \%$ & $52 \%$ & $30 \%$ \\
\hline
\end{tabular}

Source: Authors, based on farm accountancy data networks (FADN) and farm-level indicators for new topics in policy evaluation (FLINT) data.

All farms were family farms, with full agricultural training, and the average age of managers was 51.7 years. It is worth mentioning that female managers were more predominant in permanent crops and olive farms, in contrast to the other farm types (Table 2). Regarding the economic size of farms, as determined by FADN standard output (SO), the majority of permanent crop farms (58\%), arable crops farms $(47 \%)$, and livestock farms $(58 \%)$ were considered large (SO $>€ 25,000)$. The majority of olive tree farms $(48 \%)$ were considered medium ( $\mathrm{SO} € 8000-25,000)$, while presenting the largest percentage of small farms $(17 \%)$ compared to other farm types $(\mathrm{SO}<€ 8000)$. In addition, there were no very large farms in the case of olive tree farms $(\mathrm{SO}>€ 50,000)$, whereas small farms were not observed in the case of livestock farms $(\mathrm{SO}<€ 8000)$.

\subsection{Description of Sustainability Indicators at the Farm Level}

A set of indicators was selected to comprehensively and reliably represent the farming systems, encountering the complexity and the multifunctional character of Greek agriculture. Within the FLINT project, an extensive literature review identified a selection of core variables and themes of sustainability [6]. The themes cover the three sustainability dimensions known as "triple $\mathrm{P}^{\text {", }}$ i.e., planet (environmental), people (social), and profit (economic) (Table 3), following the definition of the United Nations, i.e., that sustainable development pertains equally to ecological, social, and economic issues. The indicators of sustainability at the farm level were chosen from the wide list of 33 topics developed by the FLINT project consortium, taking into account policy needs [48] and consultation from stakeholders and FLINT partners [49,50]. The mean value of each indicator for each farm type corresponds to a sub-criterion, which is used as the input by the AHP model (see also Figure 3).

Table 3. Set of sustainability indicators at the farm level.

\begin{tabular}{|c|c|c|c|}
\hline Sustainability Dimension & Indicator & Unit & Source \\
\hline \multirow{4}{*}{ Environmental } & Greenhouse gas (GHG) emissions at farm & $\mathrm{tCO}_{2} \mathrm{eq} / \mathrm{ha}$ & FLINT e_14_1 \\
\hline & Percentage of farm UAA with nitrate risk & $\%$ & FLINT e_10_4 \\
\hline & Water consumption per kg of product & $\mathrm{Lt} / \mathrm{kg}$ & FLINT e_16_1 \\
\hline & Pesticide usage & $\mathrm{Kg} / \mathrm{ha}$ & FLINT e_4_1 \\
\hline \multirow{3}{*}{ Social } & Advisory contacts per year per holding & $\mathrm{n}$ & FLINT s_1_1 \\
\hline & Satisfaction with quality of life & $\mathrm{n}$ & FLINT s_6_4 \\
\hline & Social diversification index & Count & FLINT s_7_2 \\
\hline \multirow{3}{*}{ Economic } & Total output/total input & Euro & FADN SE132 \\
\hline & Total subsidies/family farm income & Euro & FADN SE605/SE420 \\
\hline & (Family farm income/family work unit)/reference income & Euro & FADN SE430 \\
\hline
\end{tabular}

Source: Authors, based on FLINT and FADN data sources. 


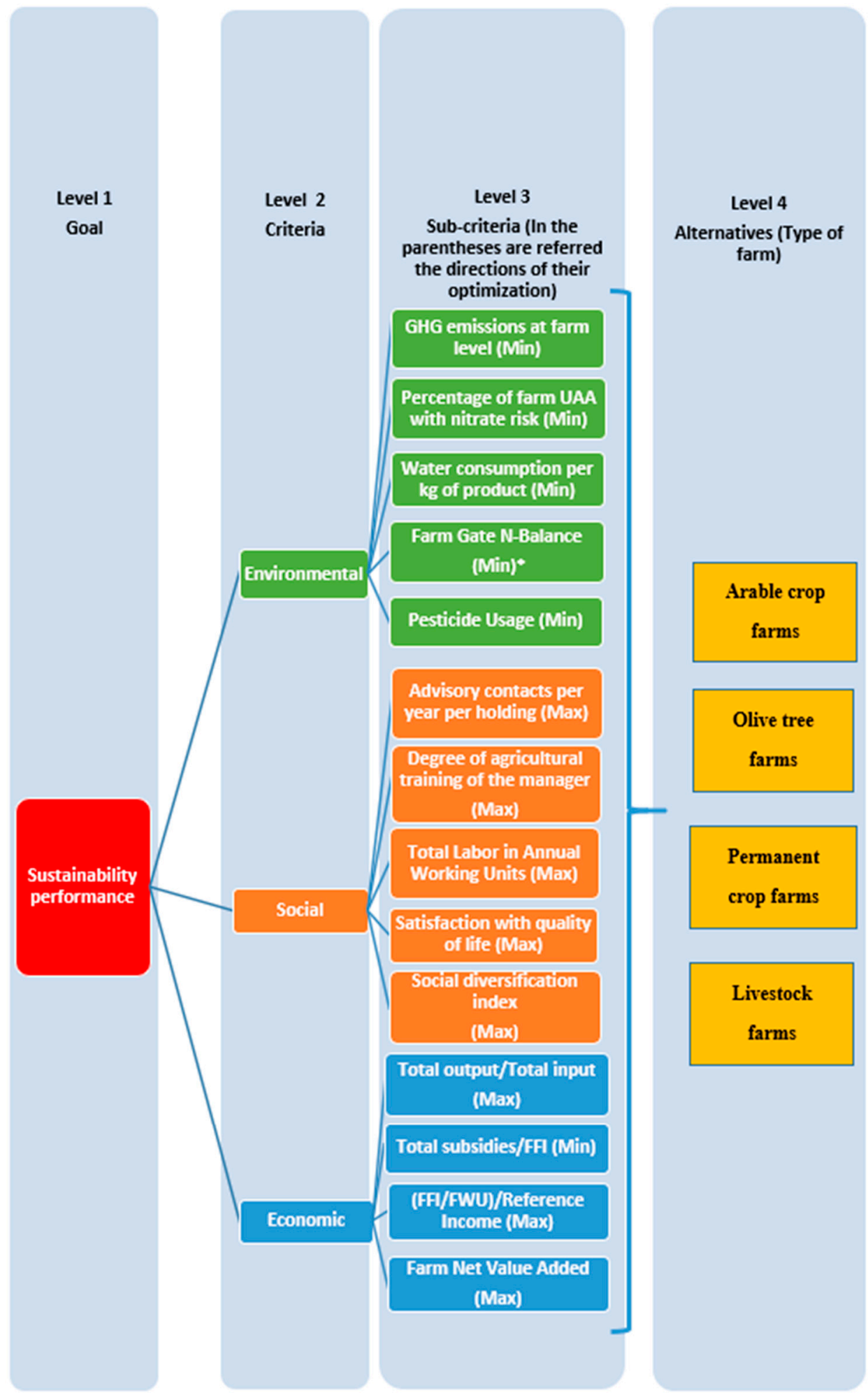

Figure 3. Analytical hierarchy process (AHP) model for the assessment of the sustainability performance; $\left(^{*}\right)$ Values that tend to approach zero are considered more ideal than others that are far from zero; in the case of negative values, they are converted to absolute values so that they are directly comparable to positive values. 


\subsubsection{Environmental Indicators}

GHG emissions at farm level: The GHG emission per farm (tons of carbon dioxide equivalent, i.e., $\mathrm{tCO} 2$ eq.) is a primary policy target and is estimated using the tier 1 and tier 2 procedures of the Intergovernmental Panel on Climate Change-IPCC [48]. The best value for this indicator is a low one, which means a more environmentally sustainable farm. It provides useful information about the applied production practices and more broadly about the agricultural systems. Moreover, it supports the long-term evaluation of GHG production and is enhanced with the relevant information on the right Common Agricultural Policy (CAP) actions for climate change mitigation. It also helps to adjust the applied strategy for Greek farming systems and practices that contribute positively to reducing GHG emissions.

Percentage of farm UAA with nitrate risk: The level of nitrate risk is crucial for economic, environmental, and health issues [48,51]. Farmers have to care for the cautious suitability of crop requirements of fertilizers and nutrients in order to adjust optimal cost-effective and environmentally beneficial management for the farm [52]. A low value of this indicator indicates a more environmentally sustainable level for the given farm.

Water consumption per $\mathrm{kg}$ of product: Water is an essential environmental factor which contributes to sustainable economic growth. Water, as a limited recourse in the Mediterranean area, is therefore a central theme to include in the sustainability assessment regarding water consumption in agriculture. An effective strategy regarding water efficiency can provide a significant contribution to estimate the level of sustainability. Hence, the level of water consumption through irrigation was estimated. The water footprint indicator reveals the volume of water consumed by the unit of the product obtained. The lower the value of this indicator, the more environmentally sustainable the farm is considered to be [53].

Farm gate $\mathrm{N}$-balance: The information about the level of nitrogen use is crucial at the farm level. It helps farmers to discern conditions to save on fertilizer costs, decrease greenhouse gas emissions, and enhance agronomic efficiency and environmental sustainability. It supports optimal fertilizer management, with no adverse impact on either the profitability of production or the environment. A suggested indicator in the FLINT was the farm gate N-balance [48]. The farm gate approach focuses on imports and exports, over which the farmers may apply direct control. Values that tend to approach zero are considered ideal. In the case of negative values, they are converted to absolute values so that they are directly comparable to positive values. Consequently, the lower the absolute value of this indicator, the more environmentally sustainable the farm is considered to be.

Pesticide usage: The pesticide usage, or pesticide risk score, has many impacts on farmers, consumers, and the sustainability of agricultural sectors. Pesticides can have a significant effect on water quality and can affect water quality for both human and livestock consumption, and aquatic habitats and wildlife [54]. The indicator refers to the quantities and diverse types of different types of pesticides used on farms. This information is used to calculate a farm-level pesticide risk score [48]. A low value for this indicator is preferable, since it showcases that the farm is environmentally sustainable.

\subsubsection{Social Indicators}

Advisory contacts per year per holding: The total number of contacts with advisory services per year was used to operationalize the type and the range of themes on which farmers seek advice. This indicator is a composite one, and it refers to advice-need events related to accountancy, management or investments, crop and animal production, and other gainful activities. The role of advisory services is essential to support the dissemination of innovation, and enhance the productivity and improve environmental performance [55]. Farms with access to advisory services are better informed and produce better knowledge, and, therefore, may support innovative actions. The higher the value of this indicator, the more socially sustainable the farm is considered to be.

Degree of agricultural training of the manager: The level of education represents the credentials of human resources. The higher the value of this indicator, the more socially sustainable the farm is considered to be. 
Total labor in annual working units: The total labor input, expressed in annual work units or full-time person equivalents, is an indicator that counts the potential of an agricultural sector to retain or even augment the number of jobs in an area, usually a remote, mountainous, or less favored rural area. Thus, it is an indicator of significant importance, especially during the crisis period which the Greek economy has been experiencing within the last ten years. The higher the value of this indicator, the more socially sustainable the farm is considered to be.

Satisfaction with quality of life: This indicator, as a fundamental dimension in social sustainability, tries to measure the quality of jobs in the agricultural sector. This helps to determine links between life quality perceptions and sustainability conditions [56]. The indicator is measured on a scale from zero to ten. A higher value indicates a more socially sustainable farm.

Social diversification index: The social diversification index describes the openness of the farmer. It refers to the growth of activities both inside and outside the farm. It accounts for the total number of activities. It is a clear indication of a significant livelihood strategy of a farm, denoting the range of diversification activities, both at the farm and the farm household level [48]. The higher the value of this indicator, the more socially sustainable the farm is considered to be.

\subsubsection{Economic Indicators}

The evaluation of economic sustainability focuses on the viability, productivity, and dependence of the relative farming systems. Short-term and long-term viability refer to the level of profitability, the level of support from subsidies (which determine autonomy), and the long-term sustainability. Four indicators were used to describe the economic pillar. More specifically, the total output/total input, total subsidies/farm family income, farm family income per family labor unit compared to the reference income, and farm net value added.

Total output/total input: The total output per total input indicator refers to the total output of crops and crop products, livestock, and livestock products, and of the other output, divided by the total input costs linked to the agricultural activity of the holder and those which are related to the output of the accounting year. This indicator is a measure of productivity at the farm level. The higher the value of this indicator, the more economically viable the farm is considered to be.

Total subsidies/farm family income: Total subsidies (excluding investment) are compared with the farm family income (FFI) to determine to what extent the FFI depends on subsidies, and, consequently, how sensitive it could be in the case of policy changes. FFI consists of two components, namely, FFI from the market and subsidies. Therefore, if the FFI from the market is less than zero (i.e., when cash expenses and depreciation exceed farm output), the index total subsidies/FFI will be higher than $100 \%$. The lower the value of this indicator, the more economically viable the farm is considered to be.

Farm family income/family work unit compared to the reference income: Family farm income is expressed by the per family work unit and compared to the reference income, i.e., the mean income of a worker in the non-agricultural sectors of the economy. This indicator reflects a socio-economic approach to farm economic viability, as it encompasses two different dimensions; firstly, the reproduction of a farm's productive system, since with a net farm income greater than zero, the farm revenue covers both all cash expenses and the depreciation, and secondly, the support of the standard of living of the farm household. It is possible to assess to what extent the needs of the household members are fulfilled by comparing the FFI/FWU with the poverty line and the reference income. Thus, we consider a farm as economically viable if it attains an FFI/FWU value greater than $80 \%$ of the reference income. The higher the value of this indicator, the more economically viable the farm is.

Farm Net Value Added (FNVA): The farm net value added indicator is the remuneration to the fixed factors of production (work, land, and capital), whether they are external or family factors. The higher the value of this indicator, the more economically viable the farm is. 


\section{Results}

\subsection{Environmental Performance}

As for the local priority rankings of the environmental sub-criteria, according to experts, the farm gate N-balance has the highest weight at $50 \%$, followed by pesticide usage at $25 \%$, percentage of farm UAA with nitrate risk at $12 \%$, water consumption per $\mathrm{kg}$ of product at $8 \%$, and GHG emissions at $5 \%$ (see also Figure 4 and Table A1 in the Appendix A). The overall environmental performance shows that livestock farms rank first, with marginal differences from olive tree farms (see also Figure 4 and Table A2 in the Appendix A). Then, permanent crop farms followed, while the arable crop farms have a significant difference from all other examined farm systems. It is also worth noting that livestock farms outperform all other farming systems in three out of the five sub-criteria (see also Figure 4 , Tables 4 and $\mathrm{A} 2$ in the Appendix A).

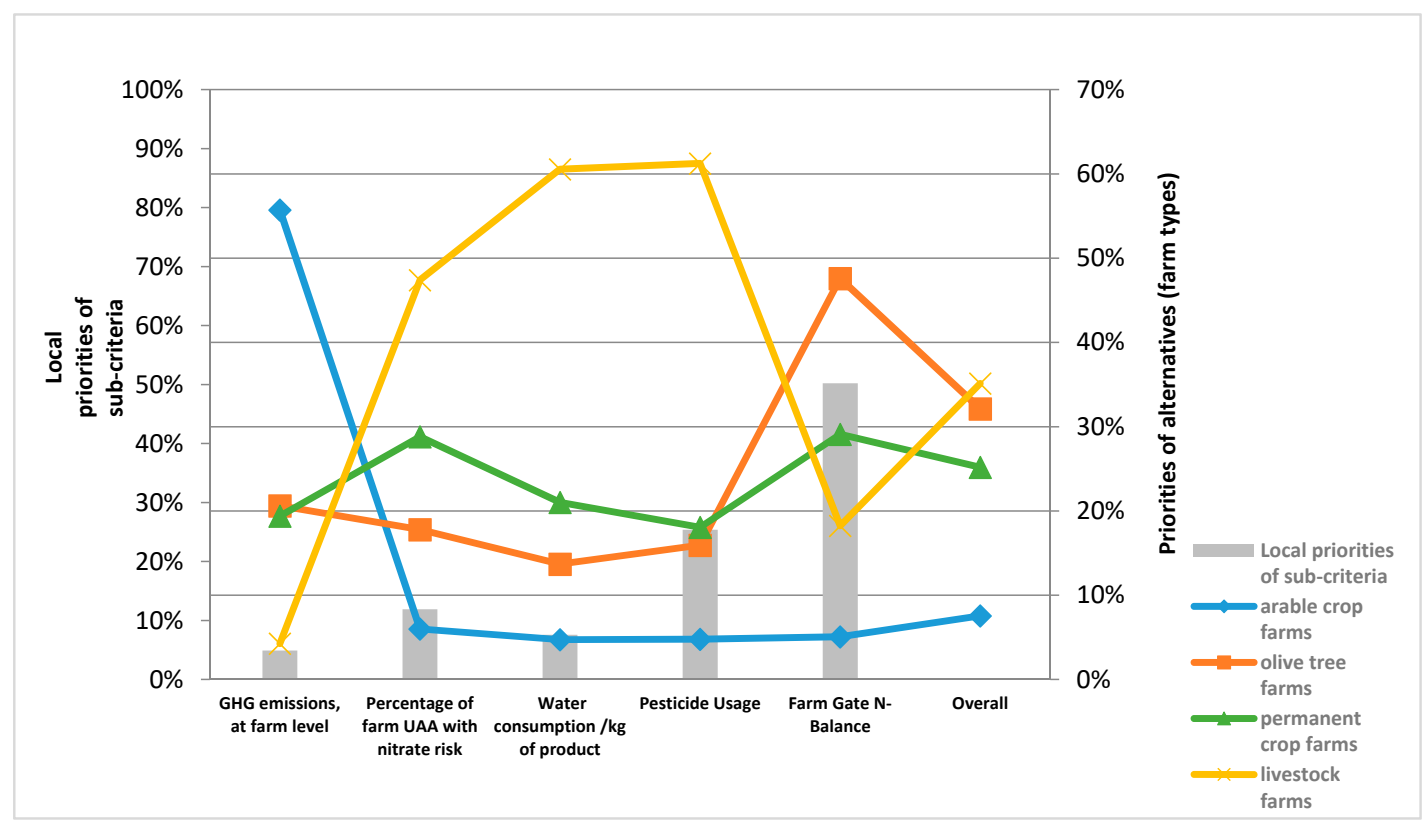

Figure 4. Performance of farms per environmental sub-criterion and overall.

Table 4. Environmental sub-criteria (mean values per farm type).

\begin{tabular}{|c|c|c|c|c|c|}
\hline & $\begin{array}{c}\text { GHG } \\
\text { Emissions at } \\
\text { the Farm Level } \\
\left(\mathrm{tCO}_{2} \mathrm{eq} / \mathrm{ha}\right)\end{array}$ & $\begin{array}{c}\text { Percentage of } \\
\text { Farm UAA with } \\
\text { Nitrate Risk }\end{array}$ & $\begin{array}{c}\text { Water } \\
\text { Consumption } \\
\text { per } \mathrm{kg} \text { of } \\
\text { Product }(\mathrm{Lt} / \mathrm{kg})\end{array}$ & $\begin{array}{c}\text { Pesticide } \\
\text { Usage (Kg/ha) }\end{array}$ & $\begin{array}{c}\text { Farm Gate } \\
\text { N-Balance } \\
\text { (Kg/ha) }\end{array}$ \\
\hline Arable crop farms & 0.24 & $61 \%$ & 710.86 & $8.32 \times 10^{-4}$ & 139.69 \\
\hline Olive tree farms & 1.22 & $42 \%$ & 126.16 & $2.88 \times 10^{-4}$ & 44.11 \\
\hline Permanent crop farms & 1.44 & $35 \%$ & 120.79 & $2.64 \times 10^{-4}$ & 72.59 \\
\hline
\end{tabular}

\subsection{Social Performance}

In the case of the social sub-criteria, the ranking formed by the responses of the experts was as follows. The total labor in annual working units has a weight of $44 \%$, advisory contacts per year per holding has a weight of $29 \%$, satisfaction with quality of life has a weight of $13 \%$, degree of agricultural training of the manager has a weight of $8 \%$, and, finally, the social diversification index has a weight of $5 \%$ (see also Figure 5 and Table A1 in the Appendix A). The highest overall social performance was observed for livestock farms followed by arable crop farms, permanent crop farms, and, finally, by olive tree farms (see also Figure 5 and Table A2 in the Appendix A). The high performances of livestock farms on two 
major sub-criteria (total labor in annual working and advisory contacts units per year per holding) explain their high overall social performance (see also Figure 5, Tables 5 and A2 in the Appendix A).

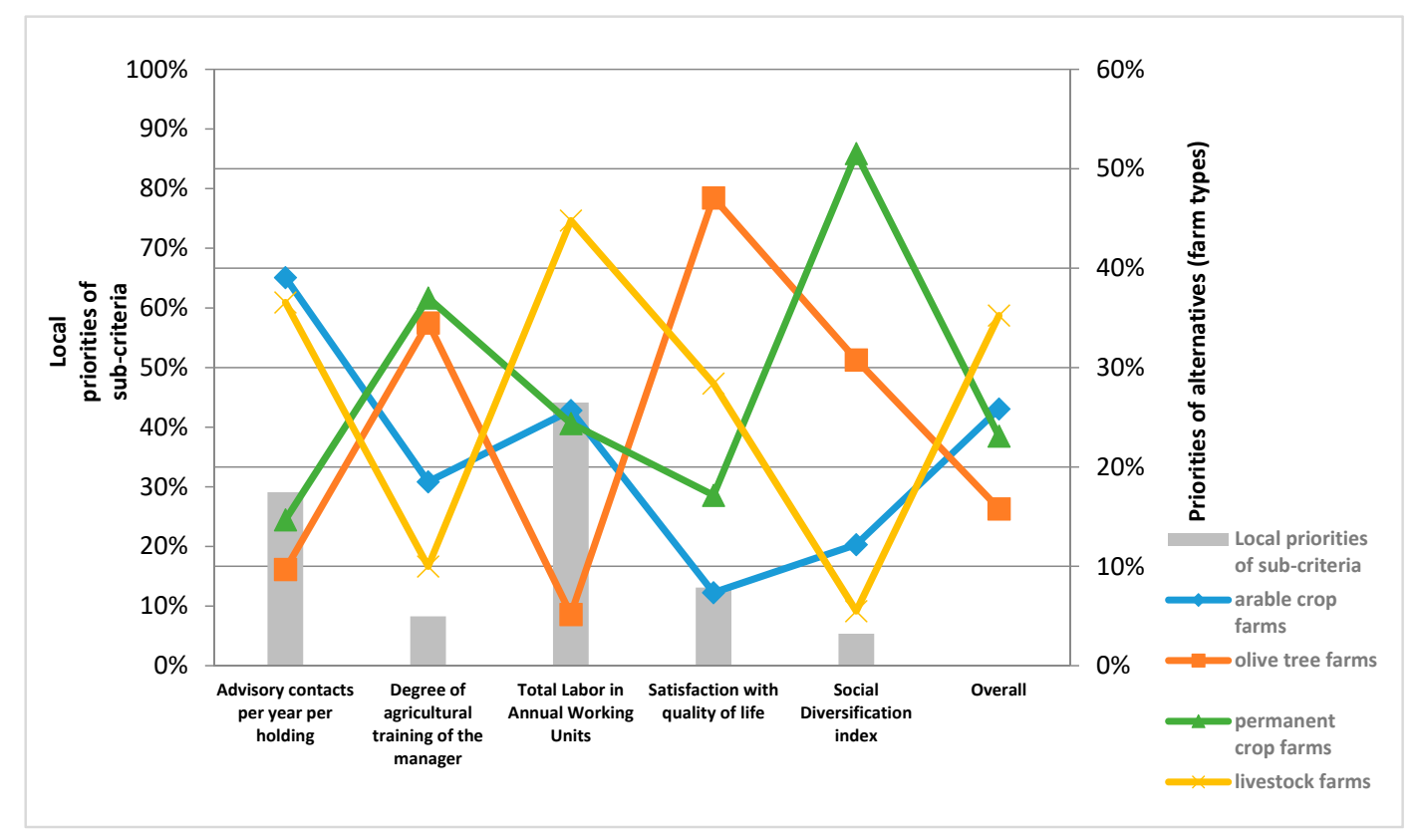

Figure 5. Performance of farms per social sub-criterion and overall.

Table 5. Social sub-criteria (mean values per farm type).

\begin{tabular}{cccccc}
\hline & $\begin{array}{c}\text { Advisory } \\
\text { Contacts per } \\
\text { Year per } \\
\text { Holding (n) }\end{array}$ & $\begin{array}{c}\text { Degree of } \\
\text { Agricultural } \\
\text { Training of the } \\
\text { Manager (Category) }\end{array}$ & $\begin{array}{c}\text { Total Labor in } \\
\text { Annual Working } \\
\text { Units (n) }\end{array}$ & $\begin{array}{c}\text { Satisfaction } \\
\text { with Quality } \\
\text { of Life (n) }\end{array}$ & $\begin{array}{c}\text { Social } \\
\text { Diversification } \\
\text { Index (count) }\end{array}$ \\
\hline Arable crop farms & 37.6 & 2.07 & 1.29 & 5.33 & 1.27 \\
Olive tree farms & 12.7 & 2.39 & 0.96 & 7.43 & 1.30 \\
Permanent crop farms & 15.8 & 2.44 & 1.27 & 6.06 & 2.00 \\
Livestock farms & 33.5 & 1.75 & 1.80 & 6.29 & 0.92 \\
\hline
\end{tabular}

\subsection{Economic Performance}

According to experts, the economic sub-criteria ranking was as follows: (FFI/FWU)/reference income has a weight of $50 \%$, total output/total input has a weight of $22 \%$, FNVA has a weight of $21 \%$, and total subsidies/FFI has a weight of $6 \%$ (see also Figure 6 and Table A1 in the Appendix A). In terms of the prioritization of alternatives or overall economic performance, permanent crop farms are the first (see also Figure 6 and Table A2 in the Appendix A). They differ significantly from all other types of farms, followed by olive tree farms, livestock farms, and, finally, arable crop farms. It is also worth noting that permanent crop farms outperform the other crops in all economic sub-criteria, which explains their high-performance range over other farming systems (see also Figure 6, Tables 6 and A2 in the Appendix A). Specifically, permanent crops score a lower dependency on subsidies, which indicates that family farm income depends on market income and not on external sources like subsidies. The productivity scores were higher compared to all other analyzed sectors, meaning that permanent crops have a high value of output and lower costs. Moreover, farm family income had the highest score, reflecting a primary indicator of farm economic viability in combination with the revenues to cover all cash expenses, and the depreciation contributes to the support of farm household standard of living. Finally, the farm net value added, which represents the remuneration of the fixed factors of production, scored higher than all other sectors. 


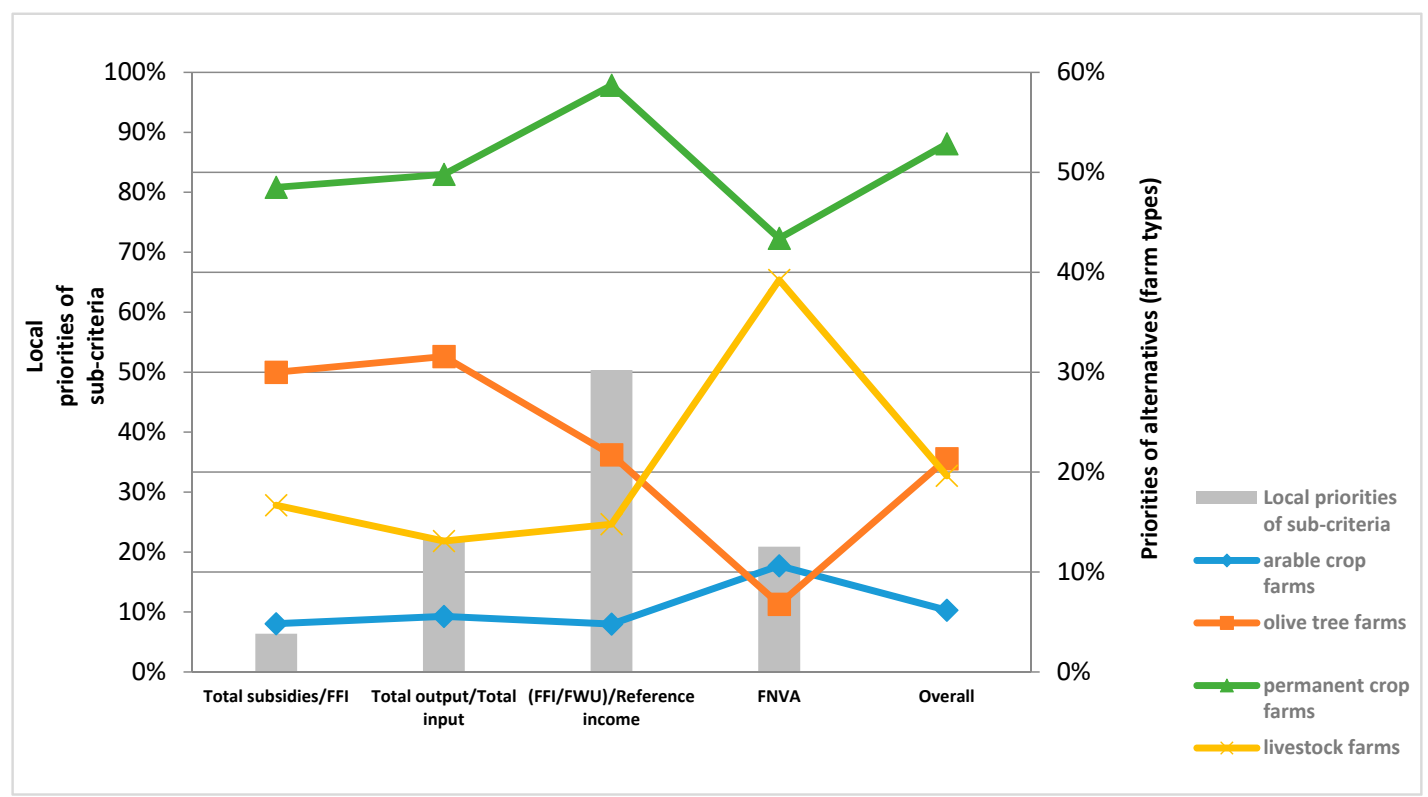

Figure 6. Performance of farms per economic sub-criterion and overall.

Table 6. Economic sub-criteria (mean values per farm type).

\begin{tabular}{ccccc}
\hline & $\begin{array}{c}\text { Total } \\
\text { Subsidies/Farm } \\
\text { Family Income }\end{array}$ & $\begin{array}{c}\text { Total Output/ } \\
\text { Total Input }\end{array}$ & $\begin{array}{c}\text { (Family Farm } \\
\text { Income/Family } \\
\text { Work Unit)/ } \\
\text { Reference income }\end{array}$ & $\begin{array}{c}\text { Farm Net Value } \\
\text { Added (€) }\end{array}$ \\
\hline Arable crop farms & $345 \%$ & $78 \%$ & $54 \%$ & 17,850 \\
Olive tree farms & $32 \%$ & $202 \%$ & $158 \%$ & 16,875 \\
Permanent crop farms & $25 \%$ & $258 \%$ & $202 \%$ & 26,457 \\
Livestock farms & $112 \%$ & $152 \%$ & $140 \%$ & 25,567 \\
\hline
\end{tabular}

\subsection{Overall Sustainability Performance and Sensitivity Analysis}

Aggregating the results of the previous sections, we may observe that livestock farms outperform all other farms in two criteria; namely, the environmental and social criteria (see also Figure 7 and Table A2 in the Appendix A). On the other hand, arable crop farms occupy the last position in the environmental and economic criteria. It is also worth noting the clear superiority of the permanent crop farms in the economic criterion, a situation which is not observed in the other two criteria. In the process of evaluating the overall sustainability performance of each alternative (farm type), in addition to the basic distribution of equal weights $(0.33 / 0.33 / 0.33)$ among criteria, we have studied three alternative policy scenarios from the policy maker's perspective. For each preference scenario, the weight distribution among criteria was adjusted accordingly $(0.50 / 0.25 / 0.25)$. As can be seen, permanent crop farms rank first in the baseline scenario of equal weights, followed by livestock farms with a slight difference (see also Figure 8 and Table A2 in the Appendix A). Olive tree farms are in third place with a distinct difference, while arable crop farms rank last with a big difference. When it comes to the environment, permanent crop farms and livestock are virtually the same, followed by olive tree farms, with a decreased difference compared to the baseline scenario, while, for arable crop farms, the distance becomes wider. In the case of social preference scenario, permanent crop farms and livestock are virtually the same, followed by olive tree farms with an increased difference compared to baseline scenario, while arable crop farms rank last but decrease the gap significantly. Finally, in the case of the economic preference scenario, the sustainability performance of permanent crop farms improves significantly; as a result, they rank first with a significant difference over livestock farms, which reveal a lower performance than other scenarios. Olive tree farms are in third place, with a 
distinct difference, revealing lower sustainability performance compared to the baseline scenario, while arable crop farms rank last.

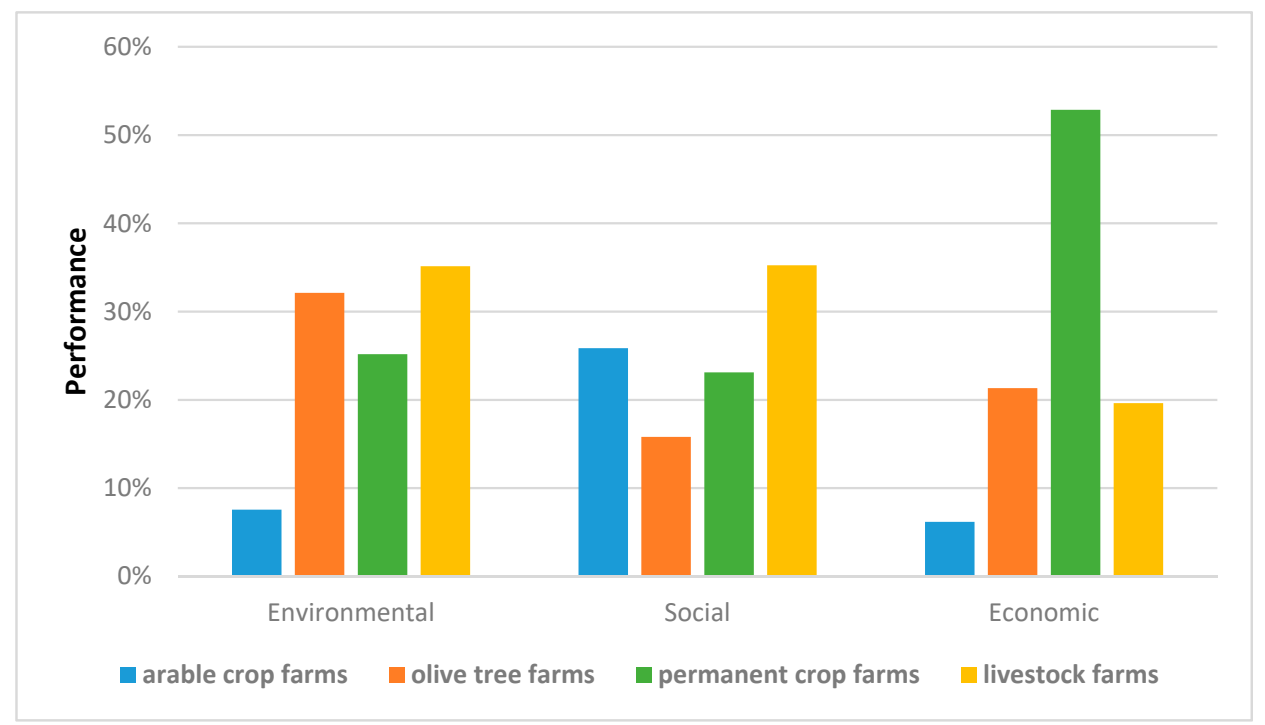

Figure 7. Performance of farms per criterion.

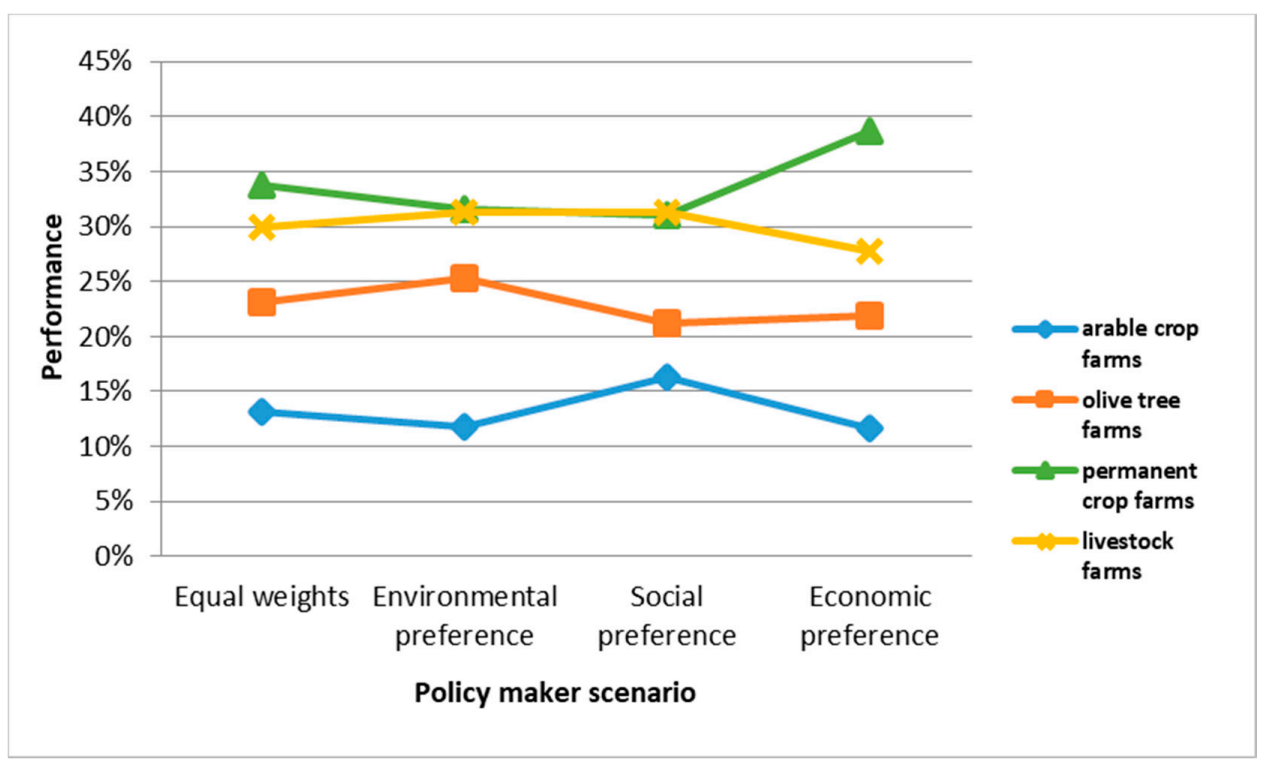

Figure 8. Overall sustainability performance per policymaker scenario.

\section{Discussion}

This study contributes to filling a gap in the integrated assessment of farm-level sustainability for some critical Greek farming systems. It is worth mentioning that two of the examined systems concern permanent crops, for which only a few sustainability assessment methods have been applied so far [57]. A series of methodological and empirical issues emerge from the preceding analysis.

Sustainability assessment is not an easy task, especially when it is conducted across all pillars and through composite indicators. Composite indicators are easy to interpret, while they convey and summarize valuable information in complex, multi-dimensional issues. On the other hand, their interpretation could be ambiguous, because they can send misleading policy messages [58]. Two further problems are the subjectivity of the process of assigning weights to individual indicators, which, along with their aggregation, is the essential stage in the process of constructing composite 
indicators [59]. This ambiguity is mitigated by the fact that the opinions of experts reflect, at least to some degree, the "preferences" of the society on the debated and multi-faceted issue of sustainability. Therefore, future research could broaden the pool of experts (whose opinions are used to assign weights to separate indicators) with other stakeholders from the agri-food system, such as policymakers, farmers, cooperative members, etc. Additionally, future research should include small farms, which make up the backbone of Greek agriculture.

Taking into account the appeal for broadening the datasets of the established monitoring tools [20], we have shown that the enrichment of FADN data with a series of farm-level information from the FLINT project, concerning environmental and social aspects of farm functioning, provides a meaningful set of indicators that enable a thorough sustainability assessment.

Assessing sustainability at the farm level is a powerful tool that can be used for a variety of purposes, such as the improvement in the governance of the agricultural sector [59] and the facilitation of the marketing of food products [60]. It can also support farmers to carry out detailed diagnoses to find the strengths and weaknesses of farms, thus contributing to the construction of a viable farm development plan. Also, the findings of this study can prove useful in identifying the actions needed to ensure the long-term sustainability of the examined systems, as well as in the formation of strategies for sustainable development in both sectoral and spatial terms.

A significant finding of this research is that although arable crop farms have received relatively more financial support over time, mainly in the form of direct payments, they have not been able to reduce the gap in the criterion of economic performance significantly. Similarly, while the agri-environmental measures in Greece were applied primarily to arable crops, our analysis shows that arable crop farms lag behind other sectors in terms of environmental performance criteria.

Moreover, Prosperi et al. [61] claimed that the high sustainability performance of agri-food systems implies an enhanced ability to withstand shocks and stressors of various kinds, i.e., it renders these systems less vulnerable. Consequently, the findings of this study assume significant importance in view of all challenges faced by Greek (and more generally the Mediterranean) agriculture, especially climate change, economic crises, and other stressors. Furthermore, the sustainability performance variation of the farming systems under consideration can be investigated in the light of future changes, such as climate change. In particular, foresight scenarios can be used for crop yields and prices based on the Fifth Intergovernmental Panel on Climate Change (IPCC) report, which takes into account the possible global climate and socio-economic changes. We should not forget that the dual entity farm firm/farm household is a system that is part of a broader hierarchy of agriculture-related systems. Therefore, a systemic approach is needed, whereby sustainability is seen as an emergent property, related to particular levels within the hierarchy. As Webster [62] rightly points out, "its operational definition at the farm level thus may not apply at other levels in the hierarchy."

The proposed methodology has enabled us to identify both intra- and inter-agricultural system heterogeneity with regard to the sustainability performance of different farms across the sub-criteria in each of the three dimensions (pillars). In the social dimension, this variation is more pronounced. Nevertheless, the picture is much clearer when the overall sustainability assessment is conducted. Interestingly, it seems that three "typical" Mediterranean farming systems, as practiced by professional farms in Greece (permanent crops, olive trees, and sheep), are more sustainable than arable crops. In the case of professional sheep farms, the high sustainability performance confirms previous findings in the literature $[63,64]$. This study could support the role of specific agricultural sectors and consequently farmers through compensating them according to their significant contribution to more sustainable farming practices. Given the multi-dimensional nature of any sustainability assessment, some room should be given for flexibility in the use of sustainability performance indicators.

As we have seen, the relative ranking of the examined farming systems seems to be consistent across four different policy priorities. This finding implies that even under diverse prioritization concerning the three pillars of sustainability, permanent crops, olive trees, and sheep will be expected 
to outperform arable crops. Hence, the proposed varied prioritization of the three pillars can aid policymakers to have a clear picture of the expected sustainability performance of each farming system.

In addition, this analysis can support policy advice and improve the applied institutional framework under the new CAP (2021-2027), where the pursuit of a sustainable agricultural sector is much more explicit than before, through three general and nine specific objectives [65]. The proposed methodology can support a more 'holistic' approach to the new architecture of the CAP, i.e., a view that can transcend the individual specific objectives of the new CAP. In addition, mandatory sector-specific interventions are envisaged in the CAP strategic plan to be developed by each country. More concretely, a thorough justification will be required for the choice of the sectors to be targeted, as well as for the various interventions which will be specific to each of these sectors. Additional requirements for sectoral and spatial specifications are foreseen for both the nine specific objectives of the new CAP and the needs, which after their identification, will have to be prioritized and ranked.

In this context, the findings of this study could prove very useful. For example, three out of four economic indicators we have used in our study are directly related to all impact indicators of the first specific objective of the new CAP; similar matches exist for some of our social and environmental indicators (see Appendix A Table A3 for details). Likewise, the other economic indicator we have used (total output/total input) is related to total factor productivity (TFP), which is a 'context indicator' proposed for the assessment of the second specific objective of the new CAP. Also, TFP can be improved with new investments, whose effectiveness can be enhanced through better targeting and design. Our analysis can support such an endeavour. Indicatively, the following investment priorities for the sectors considered may be mentioned: (a) the adoption and planting of new citrus varieties, i.e., a reorganization of the system through new investments, for opening new export markets; (b) investments for the promotion of the specific identities of various extra virgin olive oils, based on the valuation of positive externalities provided by this system; (c) collective action initiatives, including investments, for the substantiation of the unique identity of dairy products produced by sheep milk, such as 'feta' cheese, which has been a designated geographical indication status.

Finally, we have to highlight that this pilot research indicates some limitations due to the small sample size and the use of one-year data. The sample of farmers may have a selection bias as it was not a real random one. Furthermore, in some cases, the variables may have been influenced by specific conditions such as weather that affect either yield conditions or price fluctuations for the referring year. Other limitations may be referred to, including either missing data or incomplete information from the farmers' side, as a few of them record their data. Available data for all farm types and more years will support the learning effects to better explain the factors that contribute to the sustainability and elucidate the cause-effort relationships for better decision management at the farm and institutional level.

\section{Conclusions}

The objective of this paper was to conduct a comparative assessment of the sustainability performance of four typical farming systems in Greece using an AHP method to aggregate sets of economic, social, and environmental sustainability indicators. The preceding analysis has yielded some interesting results, from both a methodological and an empirical point of view.

Despite the large amount of data needed, the concurrent consideration of all pillars of sustainability through AHP at the farm level, based on an enriched database of FADN, can provide a meaningful set of indicators that enable a thorough sustainability assessment. By applying the proposed methodology, we have identified significant intra- and inter-agricultural system heterogeneity in regard to the sustainability performance of different farms, as well as a clear ranking of the relative performance of the examined systems. At least two of the studied farming systems were found to be both extensive and sustainable in economic, social, and environmental terms. In addition, three "typical" Mediterranean farming systems, as practiced by professional farms in Greece (permanent crops, olive trees, and sheep), were observed to be more sustainable than arable crops. 
Far from being "neutral" or "objective", composite indicators for each of the pillars of sustainability facilitate the relative ranking of the examined systems. Moreover, the proposed methodology enables the inclusion of sustainability assessment into policy formation by assigning the three pillars of sustainability different weights. We have seen that the relative ranking holds under some possible varied priorities of policymakers. Future research efforts could focus on developing approaches to assess the sustainability performance to provide insights for recommendations and improvement for the long-term sustainability of farms.

Author Contributions: Conceptualization, I.T., S.M. and P.K.; methodology, S.M. and I.T.; software, S.M.; validation, S.M.; I.T. and P.K.; formal analysis, I.T.; S.M. and P.K.; investigation, I.T.; resources, I.T.; data curation, S.M. and I.T.; writing-Original draft preparation, I.T., S.M. and P.K.; writing-Review and editing, I.T., S.M. and P.K.; visualization, S.M.; supervision, I.T.; project administration, I.T.; funding acquisition, I.T. All authors have read and agreed to the published version of the manuscript.

Funding: This research was funded by the FLINT project under the EU Seventh Framework Programme under grant number 61300. The opinions expressed in this paper are not necessarily those of the EU.

Acknowledgments: Authors would like to thank farmers for their cooperation during the data collection.

Conflicts of Interest: The authors declare no conflict of interest.

\section{Appendix A}

Table A1. Local priorities of the sub-criteria according to expert judgement.

\begin{tabular}{cccc}
\hline Criterion & Sub-Criterion & $\begin{array}{c}\text { Local Priorities } \\
\text { (Weights) }\end{array}$ & Ranking \\
\hline \multirow{5}{*}{ Environmental } & GHG emissions at the farm level & 0.049 & 5th \\
& Percentage of farm UAA with nitrate risk & 0.119 & 3rd \\
& Water consumption per kg of product & 0.076 & 4 th \\
& Farm gate N-balance & 0.502 & 1 st \\
& Pesticide usage & 0.254 & 2nd \\
\cline { 2 - 4 } Social & Advisory contacts per year per holding & 0.291 & 2nd \\
& Degree of agricultural training of the manager & 0.083 & 4 th \\
& Total labor in annual working units & 0.441 & 1st \\
& Satisfaction with quality of life & 0.131 & 3rd \\
& Social Diversification Index & 0.054 & 5th \\
\cline { 2 - 3 } Economic & Total output/total input & 0.219 & 2nd \\
& Total subsidies/FFI & 0.065 & 4th \\
& (FFI/FWU)/reference income & 0.498 & 1st \\
& Farm net value added & 0.218 & 3rd \\
\hline
\end{tabular}

Table A2. Performance of farms (priorities of alternatives) per criterion, sub-criterion, and the overall sustainability performance per policymaker scenario.

\begin{tabular}{ccccc}
\hline & Arable crop Farms & Olive Tree Farms & Permanent Crop Farms & Livestock Farms \\
\hline Environmental & 0.076 & 0.321 & 0.252 & 0.351 \\
GHG emissions at the farm level & 0.557 & 0.206 & 0.194 & 0.288 \\
Percentage of farm UAA with nitrate risk & 0.060 & 0.178 & 0.210 & 0.043 \\
Water consumption per kg of product & 0.047 & 0.137 & 0.291 & 0.181 \\
Farm gate N-balance & 0.051 & 0.476 & 0.231 & 0.1806 \\
Pesticide usage & 0.048 & 0.159 & 0.147 & 0.612 \\
Social & 0.258 & 0.158 & 0.370 & 0.352 \\
Advisory contacts per year per holding & 0.391 & 0.097 & 0.244 & 0.100 \\
Degree of agricultural training of the manager & 0.185 & 0.345 & 0.171 & 0.448 \\
Total labor in annual working units & 0.257 & 0.052 & 0.515 & 0.284 \\
Satisfaction with quality of life & 0.074 & 0.471 & 0.529 & 0.055 \\
Social diversification index & 0.122 & 0.308 & 0.370 & 0.196 \\
Economic & 0.062 & 0.213 & 0.485 & 0.131 \\
Total output/total input & 0.055 & 0.316 & 0.587 & 0.167 \\
Total subsidies/FFI & 0.048 & 0.217 & 0.434 \\
(FFI/FWU)/reference income & 0.048 & 0.068 & \\
Farm net value added & 0.106 & & & 0.392 \\
\hline
\end{tabular}


Table A2. Cont.

\begin{tabular}{|c|c|c|c|c|}
\hline & Arable crop Farms & Olive Tree Farms & Permanent Crop Farms & Livestock Farms \\
\hline $\begin{array}{l}\text { Overall sustainability performance-Equal } \\
\text { weights scenario (rank) }\end{array}$ & $0.132\left(4^{\text {th }}\right)$ & $0.231\left(3^{\text {rd }}\right)$ & $0.337\left(1^{\text {st }}\right)$ & $0.300\left(2^{\text {nd }}\right)$ \\
\hline $\begin{array}{l}\text { Overall sustainability } \\
\text { performance-Environmental preference } \\
\text { scenario (rank) }\end{array}$ & $0.118\left(4^{\text {th }}\right)$ & $0.253\left(3^{\mathrm{rd}}\right)$ & $0.316\left(1^{\text {st }}\right)$ & $0.313\left(2^{\text {nd }}\right)$ \\
\hline $\begin{array}{l}\text { Overall sustainability performance-Social } \\
\text { preference scenario (rank) }\end{array}$ & $0.164\left(4^{\text {th }}\right)$ & $0.213\left(3^{\mathrm{rd}}\right)$ & $0.311\left(2^{\text {nd }}\right)$ & $0.313\left(1^{\text {st }}\right)$ \\
\hline $\begin{array}{l}\text { Overall sustainability performance-Economic } \\
\text { preference scenario (rank) }\end{array}$ & $0.114\left(4^{\text {th }}\right)$ & $0.226\left(3^{\mathrm{rd}}\right)$ & $0.385\left(1^{\mathrm{st}}\right)$ & $0.274\left(2^{\text {nd }}\right)$ \\
\hline
\end{tabular}

Table A3. Sustainability indicators at the farm level and assessment of the performance of the policy-Objectives and their respective impact indicators.

\begin{tabular}{|c|c|c|c|}
\hline $\begin{array}{l}\text { Sustainability } \\
\text { Dimension }\end{array}$ & Indicator Used in this Study & $\begin{array}{c}\text { EU Specific Objectives/ Broad Type of } \\
\text { Intervention }\end{array}$ & Impact Indicators \\
\hline \multirow{5}{*}{ Environmental } & $\begin{array}{l}\text { Greenhouse gas (GHG) } \\
\text { emissions at farm }\end{array}$ & $\begin{array}{c}\text { Contribute to climate change mitigation } \\
\text { and adaptation, as well as } \\
\text { sustainable energy }\end{array}$ & $\begin{array}{l}\text { I.10 Reducing GHG emissions from } \\
\text { agriculture: Contribute to climate } \\
\text { change mitigation }\end{array}$ \\
\hline & $\begin{array}{l}\text { Percentage of farm UAA with } \\
\text { nitrate risk }\end{array}$ & $\begin{array}{l}\text { Foster sustainable development and } \\
\text { efficient management of natural resources } \\
\text { such as water, soil and air }\end{array}$ & $\begin{array}{l}\text { I.14 Improving air quality: Reduce } \\
\text { ammonia emissions from agriculture }\end{array}$ \\
\hline & $\begin{array}{l}\text { Water consumption } \\
\text { per kg of product }\end{array}$ & $\begin{array}{l}\text { Foster sustainable development and } \\
\text { efficient management of natural resources } \\
\text { such as water, soil and air }\end{array}$ & $\begin{array}{l}\text { I.17 Water Exploitation Index Plus (WEI+): } \\
\text { Reducing pressure on water resource }\end{array}$ \\
\hline & Farm gate N-balance & $\begin{array}{l}\text { Foster sustainable development and } \\
\text { efficient management of natural resources } \\
\text { such as water, soil and air }\end{array}$ & $\begin{array}{l}\text { I.16 Nitrate in ground water Reducing } \\
\text { nutrient leakage: Percentage of ground } \\
\text { water stations with } N \text { concentration over } \\
50 \mathrm{mg} / \mathrm{L} \text { as per the Nitrate directive }\end{array}$ \\
\hline & Pesticide usage & $\begin{array}{l}\text { Improve the response of EU agriculture to } \\
\text { societal demands on food and health, } \\
\text { including safe, nutritious and sustainable } \\
\text { food, as well as animal welfare }\end{array}$ & $\begin{array}{c}\text { I.27 Reduce risks and impacts of pesticides } \\
\text { Sustainable use of pesticides }\end{array}$ \\
\hline \multirow{5}{*}{ Social } & $\begin{array}{l}\text { Advisory contacts } \\
\text { per year per holding }\end{array}$ & Knowledge exchange and information & $\begin{array}{l}\text { O.29 Number of farmers trained/ } \\
\text { given advice }\end{array}$ \\
\hline & $\begin{array}{l}\text { Degree of agricultural training } \\
\text { of the manager }\end{array}$ & Knowledge exchange and information & $\begin{array}{l}\text { O.29 Number of farmers trained/ } \\
\text { given advice }\end{array}$ \\
\hline & $\begin{array}{l}\text { Total labor in annual } \\
\text { working units }\end{array}$ & $\begin{array}{l}\text { Promote employment, growth, social } \\
\text { inclusion and local development in rural } \\
\text { areas, including bio-economy and } \\
\text { sustainable forestry }\end{array}$ & $\begin{array}{l}\text { I.22 Contributing to jobs in rural areas: } \\
\text { Evolution of the employment rate in } \\
\text { predominantly rural areas }\end{array}$ \\
\hline & Satisfaction with quality of life & $\begin{array}{l}\text { Promote employment, growth, social } \\
\text { inclusion and local development in rural } \\
\text { areas, including bio-economy and } \\
\text { sustainable forestry }\end{array}$ & $\begin{array}{l}\text { I.25 Promoting rural inclusion: Evolution of } \\
\text { poverty index in rural areas }\end{array}$ \\
\hline & Social diversification index & $\begin{array}{l}\text { Promote employment, growth, social } \\
\text { inclusion and local development in rural } \\
\text { areas, including bio-economy and } \\
\text { sustainable forestry }\end{array}$ & $\begin{array}{c}\text { I.25 Promoting rural inclusion: Evolution of } \\
\text { poverty index in rural areas }\end{array}$ \\
\hline \multirow{4}{*}{ Economic } & Total output/total input & $\begin{array}{l}\text { Enhance market orientation and increase } \\
\text { competitiveness, including greater focus on } \\
\text { research technology and digitalization }\end{array}$ & $\begin{array}{l}\text { I.6 Total factor productivity: Increasing } \\
\text { farm productivity }\end{array}$ \\
\hline & $\begin{array}{l}\text { Total subsidies/family } \\
\text { farm income }\end{array}$ & $\begin{array}{l}\text { Support Viable Farm Income and Resilience } \\
\text { across the Union to enhance food security }\end{array}$ & $\begin{array}{l}\text { I.5 Contributing to territorial balance: } \\
\text { Evolution of agricultural income in areas } \\
\text { with natural constraints } \\
\text { (compared to the average) }\end{array}$ \\
\hline & $\begin{array}{l}\text { (Family farm income/family } \\
\text { work unit)/reference income }\end{array}$ & $\begin{array}{l}\text { Support Viable Farm Income and Resilience } \\
\text { across the Union to enhance food security }\end{array}$ & $\begin{array}{l}\text { I.3 Reducing farm income variability: } \\
\text { Evolution of agricultural income } \\
\text { I.4 Supporting viable farm income: }\end{array}$ \\
\hline & Farm net value added (FNVA) & $\begin{array}{l}\text { Support Viable Farm Income and Resilience } \\
\text { across the Union to enhance food security }\end{array}$ & $\begin{array}{c}\text { Evolution of agricultural income level by } \\
\text { sectors (compared to } \\
\text { the average in agriculture) }\end{array}$ \\
\hline
\end{tabular}

Source: Authors, based on FLINT, FADN data sources and [66].

\section{References}

1. European Commission Communication “The European Green Deal". 2019. Available online: https://ec.europa. eu/info/sites/info/files/european-green-deal-communication_en.pdf (accessed on 18 December 2019).

2. Meul, M.; Van Passel, S.; Nevens, F.; Dessein, J.; Rogge, E.; Mulier, A.; Van Hauwermeiren, A. MOTIFS: A monitoring tool for integrated farm sustainability. Agron. Sustain. Dev. 2008, 28, 321-332. [CrossRef] 
3. Passel, S.; Meul, M. Multilevel and multi-user sustainability of farming systems. Environ. Impact Assess. Rev. 2012, 32, 170-180. [CrossRef]

4. Schader, C.; Grenz, J.; Meier, M.; Stolze, M. Scope and precision of sustainability assessment approaches to food systems. Ecol. Soc. 2014, 19, 42. [CrossRef]

5. Paracchini, M.L.; Bulgheroni, C.; Borreani, G.; Tabacco, E.; Banterle, A.; Bertoni, D.; Rossi, G.; Parolo, G.; Origgi, R.; De Paola, C. A diagnostic system to assess sustainability at a farm level. Agric. Syst. 2015, 133, 35-53. [CrossRef]

6. Latruffe, L.; Diazabakana, A.; Bockstaller, C.; Desjeux, Y.; Finn, J.; Kelly, E.; Ryan, M.; Uthes, S. Measurement of sustainability in agriculture: A review of indicators. Stud. Agric. Econ. 2016, 118, 123-130. [CrossRef]

7. Angevin, F.; Fortino, G.; Bockstaller, C.; Pelzer, E.; Messean, A. Assessing the sustainability of crop production systems: Toward a co common framework? Crop Prot. 2017, 97, 18-27. [CrossRef]

8. De Olde, E.; Sautier, M.; Whitehead, J. Comprehensiveness or implementation: Challenges in translating farm-level sustainability assessments into action for sustainable development. Ecol. Indic. 2018, 85, 1107-1112. [CrossRef]

9. Lampridi, M.; Sørensen, C.L.; Bochtis, D. Agricultural Sustainability: A Review of Concepts and Methods. Sustainability 2019, 11, 5120. [CrossRef]

10. Poppe, K.; Vrolijk, H. (Eds.) Farm Sustainability Data for Better Policy Evaluation with FADN; Research Report No. 2017-061; Wageningen Economic Research: Wageningen, The Netherlands, 2016; ISBN 9789463432030.

11. Uthes, S.; Kelly, E.; König, H. Farm-level indicators for crop and landscape diversity derived from agricultural beneficiaries data. Ecol. Ind. 2020, 108, 105725. [CrossRef]

12. De Olde, E.M.; Bokkers, E.A.M.; De Boer, I.J.M. The choice of the sustainability assessment tool matters: Differences in thematic scope and assessment results. Ecol. Econ. 2017, 136, 77-85. [CrossRef]

13. Food and Agriculture Organization of the United Nations. Sustainability Assessment of Food and Agriculture Systems (SAFA); FAO: Rome, Italy, 2012.

14. Organization for Economic Co-Operation and Development; Joint Research Centre of the European Commission. Handbook on Constructing Composite Indicators: Methodology and User Guide; OECD Publishing: Paris, France, 2008.

15. Van Cauwenbergh, K.; Biala, C.; Bielders, V.; Brouckaert, L.; Franchois, V.; Garcia Cidad, M.; Hermy, E.; Mathijs, B.; Muys, J.; Reijnders, X.; et al. SAFE—A hierarchical framework for assessing the sustainability of agricultural systems. Agric. Ecosyst. Environ. 2007, 120, 229-242. [CrossRef]

16. Falcone, G.; De Luca, A.I.; Stillitano, T.; Strano, A.; Romeo, G.; Gulisano, G. Assessment of Environmental and Economic Impacts of Vine-Growing Combining Life Cycle Assessment, Life Cycle Costing and Multicriteria Analysis. Sustainability 2016, 8, 793. [CrossRef]

17. De Luca, A.I.; Iofrida, N.; Leskinen, P.; Stillitano, T.; Falcone, G.; Strano, A.; Gulisano, G. Life cycle tools combined with multi-criteria and participatory methods for agricultural sustainability: Insights from a systematic and critical review. Sci. Total Environ. 2017, 595, 352-370. [CrossRef] [PubMed]

18. Alexandridis, T.K.; Andrianopoulos, A.; Galanis, G.; Kalopesa, E.; Dimitrakos, A.; Katsogiannos, F.; Zalidis, G. An Integrated Approach to Promote Precision Farming as a Measure Toward Reduced-Input Agriculture in Northern Greece Using a Spatial Decision Support System. In Comprehensive Geographic Information Systems, 1st ed.; Huang, B., Ed.; Elsevier: Oxford, UK, 2018; pp. 315-352. ISBN 978-0-12-804793-4.

19. Gaviglio, A.; Bertocchi, M.; Demartini, E. A Tool for the Sustainability Assessment of Farms: Selection, Adaptation and Use of Indicators for an Italian Case Study. Resources 2017, 6, 60. [CrossRef]

20. Kelly, E.; Latruffe, L.; Desjeux, Y.; Ryan, M.; Uthes, S.; Diazabakana, A.; Dillon, E.; Finn, J. Sustainability indicators for improved assessment of the effects of agricultural policy across the EU: Is FADN the answer? Ecol. Indic. 2018, 89, 903-911. [CrossRef]

21. Hellenic Statistical Authority. Livestock/Crops Surveys. 2019. Available online: https://www.statistics.gr/en/ statistics/agr (accessed on 5 September 2019).

22. International Olive Council. Olive Oil Production by Country. 2019. Available online: http://www. internationaloliveoil.org/estaticos/view/131-world-olive-oil-figures/ (accessed on 10 October 2019).

23. Belibasaki, S.; Sossidou, E.; Gavojdian, D. Local Breeds: Can they be a Competitive Solution for Regional Development in the World of 'Globalization'? The Cases of Greek and Romanian Local Breeds. Sci. Pap. Anim. Sci. Biotechnol. 2012, 45, 278-284.

24. Eurostat. Main Annual Crop Statistics. 2017. Available online: https://ec.europa.eu/eurostat/statisticsexplained/pdfscache/28946.pdf (accessed on 2 February 2020). 
25. Vardopoulos, I.; Falireas, S.; Konstantopoulos, I.; Kaliora, E.; Theodoropoulou, E. Sustainability assessment of the agri-environmental practices in Greece. Indicators' comparative study. Int. J. Agric. Resour. Gov. Ecol. 2018, 14, 368-399. [CrossRef]

26. European Environment Agency (EEA). Key Observed and Projected Climate Change and Impacts for the Main Biogeographical Regions in Europe. 2017. Available online: https://climate-adapt.eea.europa.eu/ knowledge/tools/urban-ast/step-0-/observedprojectedchanges.png/view (accessed on 15 January 2020).

27. Dantsis, T.; Douma, C.; Giourga, C.; Loumou, A.; Polychronaki, E.A. A methodological approach to assess and compare the sustainability level of agricultural plant production systems. Ecol. Indic. 2010, 10, 256-263. [CrossRef]

28. Bartzas, G.; Komnitsas, K. An integrated multi-criteria analysis for assessing sustainability of agricultural production at regional level. Inf. Process. Agric. 2019, in press. [CrossRef]

29. Tzouramani, I.; Zelovitis, J.; Intxaurrandieta, J.; Eguinoa, A. Sustainability of the Dairy Sheep farming: Examples from Greece and Spain. In Innovation for Sustainability in Sheep and Goats; Options Mediterraneennes A, No. 123; CIHEAM: Paris, France, 2019; pp. 457-461.

30. European Commission. Statistical Factsheet-Greece. June 2019. Available online: https://ec.europa.eu/info/ sites/info/files/food-farming-fisheries/farming/documents/agri-statistical-factsheet-el_en.pdf (accessed on 8 September 2019).

31. Antunes, P.; Karadzic, V.; Santos, R.; Beça, P.; Osann, A. Participatory multi-criteria analysis of irrigation management alternatives: The case of the Caia irrigation district, Portugal. Int. J. Agric. Sustain. 2011, 9 , 334-349. [CrossRef]

32. Abdallah, S.B.; Elfkih, S.; Parra-López, C. A Sustainability comparative assessment of Tunisian organic and conventional olive growing systems based on the AHP methodology. New Medit. 2018, 17, 51-68. [CrossRef]

33. Parra-López, C.; Calatrava-Requena, J.; de-Haro-Giménez, T. A systemic comparative assessment of the multifunctional performance of alternative olive systems in Spain within an AHP-extended framework. Ecol. Econ. 2008, 64, 820-834. [CrossRef]

34. Król, A.; Księzak, J.; Kubińska, E.; Rozakis, S. Evaluation of sustainability of maize cultivation in Poland. A prospect theory-PROMETHEE approach. Sustainability 2018, 10, 4263. [CrossRef]

35. Liu, F.; Zhang, H. Novel methods to assess environmental, economic, and social sustainability of main agricultural regions in China. Agron. Sustain. Dev. 2013, 33, 621-633. [CrossRef]

36. Radulescu, C.Z.; Rahoveanu, A.T.; Radulescu, M. A hybrid multi-criteria method for performance evaluation of romanian South Muntenia Region in context of sustainable agriculture. In Proceedings of the International Conference on Applied Computer Science, Malta, 15-17 September 2010; Deo, N., Demiral, M., Stork, M., Milkova, E., Wakamatsu, H., Tchizawa, K., Eds.; WSEAS Press: Athens, Greece, 2010; pp. 303-308.

37. Gómez-Limón, J.A.; Riesgo, L. Alternative approaches to the construction of a composite indicator of agricultural sustainability: An application to irrigated agriculture in the Duero basin in Spain. J. Environ. Manag. 2009, 90, 3345-3362. [CrossRef]

38. Santos, J.C.S.M. Viabilidad de las Explotaciones Lecheras en un Escenario de Desconexión del Apoyo y Condicionalidad: Un Estudio de Caso en el Noroeste de Portugal. Ph.D. Thesis, Universidad Politécnica de Madrid, Escuela Técnica Superior de Ingenieros Agrónomos, Madrid, Spain, 2011.

39. Petrini, M.A.; Rocha, J.V.; Brown, J.C.; Bispo, R.C. Using an analytic hierarchy process approach to prioritize public policies addressing family farming in Brazil. Land Use Policy 2016, 51, 85-94. [CrossRef]

40. Rezaei-Moghaddam, K.; Karami, E. A multiple criteria evaluation of sustainable agricultural development models using AHP. Environ. Dev. Sustain. 2008, 10, 407-426. [CrossRef]

41. Veisi, H.; Liaghati, H.; Alipour, A. Developing an ethics-based approach to indicators of sustainable agriculture using analytic hierarchy process (AHP). Ecol. Indic. 2016, 60, 644-654. [CrossRef]

42. Silva, S.; Alçada-Almeida, L.; Dias, L.C. Multi-criteria sustainability classification of dairy farms in a portuguese region. In Assessment Methodologies: Energy, Mobility and Other Real World Application, 1st ed.; Godinho, P., Dias, J., Eds.; Imprensa da Universidade de Coimbra: Coimbra, Portugal, 2010; pp. 343-364. ISBN 978-989-26-1038-2.

43. Papathanasiou, J.; Ploskas, N.; Bournaris, T.; Manos, B. A Decision Support System for Multiple Criteria Alternative Ranking Using TOPSIS and VIKOR: A Case Study on Social Sustainability in Agriculture. In Decision Support Systems VI-Addressing Sustainability and Societal Challenges; Liu, S., Delibašić, B., Oderanti, F., Eds.; Springer: Cham, Switzerland, 2016; Volume 250, pp. 3-15. ISBN 978-3-319-32876-8. 
44. Saaty, T.L. What is the Analytic Hierarchy Process? In Mathematical Models for Decision Support, 1st ed.; Mitra, G., Greenberg, H.J., Lootsma, F.A., Rijkaert, M.J., Zimmermann, H.J., Eds.; Springer: Heidelberg/Berlin, Germany, 1988; Volume 48, pp. 109-121. ISBN 978-3-642-83557-5.

45. Georgiou, D.; Mohammed, E.S.; Rozakis, S. Multi-criteria decision making on the energy supply configuration of autonomous desalination units. Renew. Energy 2015, 75, 459-467. [CrossRef]

46. Mu, E.; Pereyra-Rojas, M. Understanding the Analytic Hierarchy Process. In Practical Decision Making Using Super Decisions, 1st ed.; Springer: Cham, Switzerland, 2018; pp. 7-22. ISBN 978-3-319-68368-3.

47. Nardo, M.; Saisana, M.; Saltelli, A.; Tarantola, S.; Hoffman, A.; Giovannin, E. Handbook on Constructing Composite Indicators: Methodology and User Guide; OECD Statistics Working Papers; OECD: Paris, France, 2005.

48. Kelly, E.; Ryan, M.; Finn, J.; Hennessy, T. FLINT D1: Farm-Level Indicators for Evaluating Sustainability and Emerging New Policy Topics. 2015. Available online: https://www.flint-fp7.eu/downloads/reports/FLINT\% 20WP1_\%20D1\%204.pdf (accessed on 20 September 2019).

49. Herrera, B.; Gerster-Bentaya, M.; Knierim, A. Stakeholders' perceptions of sustainability measurement at farm level. Stud. Agric. Econ. 2016, 118, 131-137. [CrossRef]

50. Poppe, K.; Vrolijk, H. Farm Sustainability Data for Better Policy Evaluation with FADN. Wageningen Economic Research, 2017. Available online: https:/library.wur.nl/WebQuery/wurpubs/fulltext/414173 (accessed on 20 February 2020).

51. Thomas, I.A.; Buckley, C.; Kelly, E.; Dillon, E.; Lynch, J.; Moran, B.; Hennessy, T.; Murphy, P.N.C. Establishing nationally representative benchmarks of farm-gate nitrogen and phosphorus balances and use efficiencies on Irish farms to encourage improvements. Sci. Total Environ. 2020, 720, 137245. [CrossRef]

52. Quemada, M.; Lassaletta, L.; Jensen, L.S.; Godinot, O.; Brentrup, F.; Buckley, C.; Foray, S.; Hvid, S.K.; Oenema, J.; Richards, K.G.; et al. Exploring nitrogen indicators of farm performance among farm types across several European case studies. Agric. Syst. 2020, 177, 102689. [CrossRef]

53. Eguinoa, P.; Intxaurrandieta, J.M. FLINT D5.20: Water Usage, Source, and Sustainability: Examples from the Region of Navarra (Spain) and Greece. 2016. Available online: https://www.flint-fp7.eu/downloads/reports/ D5.20.pdf (accessed on 20 September 2019).

54. Levitan, L.; Merwin, I.; Kovach, J. Review: Assessing the relative environmental impacts of agricultural pesticides: The quest for a holistic method. Agric. Ecosyst. Environ. 1995, 55, 153-168. [CrossRef]

55. Herrera, B.; Gerster-Bentaya, M.; Tzouramani, I.; Knierim, A. Advisory services and farm-level sustainability profiles: An exploration in nine European countries. J. Agric. Educ. Ext. Rural Innov. Transf. 2019, 25, 117-137. [CrossRef]

56. Herrera, B.; Gerster-Bentaya, M.; Knierim, A. Farm-level factors influencing farmers' satisfaction with their work. In Proceedings of the International Conference of Agricultural Economists, Vancouver, BC, Canada, 28 July-2 August 2018.

57. Rosnoblet, J.; Girardin, P.; Weinzaepflen, E.; Bockstaller, C. Analysis of 15 years of agriculture sustainability evaluation methods. In Proceedings of the 9th ESA Congress, Warsaw, Poland, 4-6 September 2006.

58. Saisana, M.; Tarantola, S. State-Of-The-Art Report on Current Methodologies and Practices for Composite Indicator Development; Technical Report No. EUR 20408 EN; Joint Research Centre-European Commission: Ispra, Italy, 2002; 72p.

59. Gómez-Limón, J.A.; Sanchez-Fernandez, G. Empirical evaluation of agricultural sustainability using composite indicators. Ecol. Econ. 2010, 69, 1062-1075. [CrossRef]

60. Ryan, M.; Hennessy, T.; Buckley, C.; Dillon, E.J.; Donnellan, T.; Hanrahan, K.; Moran, B. Developing farm-level sustainability indicators for Ireland using the Teagasc National Farm Survey. Ir. J. Agric. Food 2016, 55, 112-125. [CrossRef]

61. Prosperi, P.; Allen, T.H.; Padilla, M.; Peri, I.; Cogill, B.R. Sustainability and Food and Nutrition Security: A Vulnerability Assessment Framework for the Mediterranean Region. SAGE Open 2014, 4, 1-15. [CrossRef]

62. Webster, P. The challenge of sustainability at the farm level: Presidential address. J. Agric. Econ. 1999, 50, 371-387. [CrossRef]

63. Sossidou, E.; Ligda, C.H.; Mastranestasis, I.; Tsiokos, D.; Samartzi, F. Sheep and Goat farming in Greece: Implications and challenges for the sustainable development of less favoured areas. Sci. Pap. Anim. Sci. Biotechnol. 2013, 46, 446-449.

64. Ragkos, A.; Theodoridis, A.; Arsenos, G. Alternative Approaches of Summer Milk Sales from Transhumant Sheep and Goat Farms: A Case Study from Northern Greece. Sustainability 2019, 11, 5642. [CrossRef] 
65. European Commission. Proposal for a Regulation of the European Parliament and of the Council, Establishing Rules on Support for Strategic Plans to Be Drawn up by Member States under the Common Agricultural Policy (Cap Strategic Plans) and Financed by the European Agricultural Guarantee Fund (EAGF) and by the European Agricultural Fund for Rural Development (EAFRD) and Repealing Regulation (EU) No 1305/2013 of the European Parliament and of the Council and Regulation (EU) No 1307/2013 of the European Parliament and of the Council; COM/2018/392 final; European Commission: Brussels, Belgium, 2018.

66. European Commission. Annexes to the Proposal for a Regulation of the European Parliament and of the Council, Establishing Rules on Support for Strategic Plans to Be Drawn up by Member States under the Common Agricultural Policy (Cap Strategic Plans) and Financed by the European Agricultural Guarantee Fund (EAGF) and by the European Agricultural Fund for Rural Development (EAFRD) and Repealing Regulation (EU) No 1305/2013 of the European Parliament and of the Council and Regulation (EU) No 1307/2013 of the European Parliament and of the Council; COM/2018/392 final; European Commission: Brussels, Belgium, 2018.

(C) 2020 by the authors. Licensee MDPI, Basel, Switzerland. This article is an open access article distributed under the terms and conditions of the Creative Commons Attribution (CC BY) license (http://creativecommons.org/licenses/by/4.0/). 